\title{
2. A HISTORY OF DORSET HILLFORT INVESTIGATION
}

John Gale

Most of Dorset's hillforts are to be found on the chalk downlands of the county but others are found on the limestone of Purbeck and in the clay vales to the extreme west of Dorset as well as those on the gravels of Poole basin. Of the 34 sites identified, more than a third have been the subject of some form of excavation but only four of these (Chalbury, Hod Hill, Maiden Castle and Pilsden Pen) could claim to have been significantly sampled. The problem is not that the sites are especially difficult to excavate but rather it is a question of scale. To understand such complex earthworks it would be preferable to excavate them completely but, generally speaking, large scale sampling should be sufficient. With hillforts, of course, the question is how large is large? This is a matter that can only be defined on a case by case basis, but certainly it is likely to be greater than $25 \%$ of the whole. Unfortunately, only two hillforts in England and Wales have achieved such attention: Crickley Hill in Gloucestershire (Dixon 1996) and Danebury in Hampshire (Cunliffe 1984), each with more than 50\% of their interiors excavated. The most closely and extensively studied of the Dorset hillforts is Maiden Castle, which has been the subject of two major excavation campaigns, Tessa and Mortimer Wheeler in the 1930s (Wheeler 1943) and Niall Shaples in the mid-1980s (Sharples 1991). Neither of these excavations sampled more than a fraction of the enclosed area, in both cases no more than $1 \%$, but the recovered evidence presents a detailed picture of life within the hillfort spanning almost the whole of the Iron Age.

Hillfort plans were first published for Eggardon Hill in the late 18th century (Hutchins 1774) whilst more detailed consideration of the form and nature of earthworks, including discussion of surface features, such as potential hut platforms and associated finds, was made by Charles Warne in the late $19^{\text {th }}$ century (Warne 1872). The acquisition of surface artefacts was taken to a whole new level by Henry Durden, whose collection of archaeological material from Hod Hill was greatly enhanced following a major period of cultivation in 1858. Large numbers of finds, most relating to the early Roman military occupation of the hillfort, were made and displayed by Durden (Longworth and Haith 1992), who also, it would appear, conducted a series of unrecorded 'examinations' into unploughed areas of the hillfort interior (Boyd-Dawkins 1900, 57). A single, poorly recorded, trench was opened within the neighbouring enclosure systems of Hambledon Hill by Edward Cunnington in 1894 followed by the more scientific excavation of 15 trenches across Hod Hill by Boyd-Dawkins in 1897 (1900). The $19^{\text {th }}$ century also saw less scientific excavation at Spettisbury where workmen digging for the Central Dorset Railway cut through the bank and ditch, disturbing numerous skeletons with little or no recording (Donaldson 1859, 190). Poundbury was spared a similar fate when Isambard Kingdom Brunel was forced, following public protest, to tunnel under the hillfort rather than cutting straight through it (Dorset County Museum 2015).

A relatively early exploration of the relatively common 'pit' features found within downland hillforts was undertaken by Colley March and Solly in early spring and summer of 1900 (1901, 28-42) at Eggardon. A total of five pits were explored. In common with observations made elsewhere during this period the excavators considered these features to be subterranean dwellings all contemporary with the occupation of the hillfort. For the time the excavations were well recorded and promptly published, the report outlining the use of vertical sectioning of the pits and observations made of the deposits and finds encountered.

In the 1930s, the wife and husband team of Tessa and Mortimer Wheeler conducted a series of excavations on Maiden Castle. This hillfort is amongst the best known of archaeological sites not only in Dorset, but also in Britain, and its occupation has a highly complex and extended chronology. The defences of the first Iron Age hillfort consisted of a single rampart and ditch, enclosing an area of approximately 6 ha. Mortimer Wheeler considered the constructional form of the early rampart as having been of box rampart form, although later excavation has thrown some doubt on this interpretation. In a box rampart, vertical timbers at the front and rear of the rampart are laced together 
by vertical timbers and the resulting 'box' packed with stone and soil. This form of construction is common to ramparts of the Hallstatt period on the continent, however it has been observed that in southern Britain, later continental styles of timber lacing were not adopted (Cotton 1954, 29). Instead, later remodelling appeared to involve the dumping of soil in order that the front of the rampart and the ditch formed a continuous steep slope.

Evidence for the occupation of the Early Iron Age hillfort at Maiden Castle is rather limited, as it had been largely destroyed or corrupted by later activity. The dating for the Early Iron Age hillfort is based exclusively upon the material culture found during the excavations, the majority of finds relating to this early phase of activity recovered from the Wheelers excavation. Most of this comprised large, undecorated situlate jars and flared-rim bowls, which correlate well with material at other sites in Dorset, notably Chalbury, and suggest a date for initial occupation probably no later than the $5^{\text {th }}$ century BC.

The early hillfort at Maiden Castle is in many ways a pale reflection of the enclosure that came to replace it during the early part of the Middle Iron Age, probably at some time between 400 and 300 $\mathrm{BC}$. The construction of the extended hillfort not only involved the enclosure of a greater area, now a massive 17.22 ha, but eventually it also involved the construction of multiple banks and ditches. Although the Wheelers excavated numerous samples of the defences, the precise dating for the sequence of construction is still not completely understood. The works were certainly completed before $100 \mathrm{BC}$, but the small size of the total sampled area and the limited precision of the dating of the ceramic sequence leaves a wide degree of latitude in which to anchor the phasing. The Wheelers also excavated the Romano-British temple within Maiden Castle, and using a coin found under the 'pavement' as a terminus post quem interpreted its construction as dating from the $4^{\text {th }}$ century $A D$ or later. The pavement was removed but re-examination of photographs by Tony King have identified the 'pavement' as the collapsed upper-storey wall of the temple, thus altering the relevance of the coin which now gives an earliest date for the collapse, not the construction.

The immediate pre-war period saw the excavation of two further hillforts at Chalbury and Poundbury. Chalbury, overlooking the modern town of Weymouth, provides some of the best evidence for the early construction and occupation of a hillfort within Dorset. The site was partially excavated in 1939 by Margaret Whitley following the completion of work at Maiden Castle (Whitley 1939), its location and status within the landscape being of a wholly different order to the latter site. The excavation programme was scheduled to continue beyond 1939, but was unfortunately curtailed by the outbreak of the Second World War later that same year. The building of the ramparts at Chalbury made use of the natural stone available by a construction method which utilised dry stone walling to create front and back revetted walls that were infilled with limestone rubble. This type of construction is not very far removed from the so-called timber box ramparts, which are a common design feature of early hillfort construction in England and Wales. Whitley excavated two sections through the single rampart and ditch, both of them displaying the same characteristics of constructional method, as well as indicating that there had been no major rebuilding of the defences after their initial construction.

Within the interior of Chalbury, Whitley examined over 70 of the circular depressions or platforms that could be seen within the turf sward, however it became clear that they were not of uniform type. The excavations of 1939 examined only four of these internal features in detail, the largest of all these being completely excavated. This proved to be a large roundhouse, whose diameter was just over $10 \mathrm{~m}$, defined by a foundation wall which survived to a height of $0.5 \mathrm{~m}$. The hut had been constructed within a pre-excavated and levelled scoop and the height of the original wall may have been as much as $1 \mathrm{~m}$. Although Whitley detected the likely presence of a floor within the hut (Whitley 1943, 107), there was little surviving evidence for an entrance or indeed an internal hearth. Within the earth fill of the hut's interior there was domestic debris, which included abundant sherds of pottery. These sherds 
consisted of mainly small carinated bowls with a haematite slip, dating to approximately $600 \mathrm{BC}$. Two further circular platforms were excavated in the interior of Chalbury hillfort, and whilst evidence for the construction of levelled areas, similar to those of the larger hut, were found, there was no sign of a stone-built foundation wall in either case. Although Whitley suggested that these features were probably working hollows, it is probable that the platforms were in fact used as sites for the construction of huts, but their form must have been relatively light not to leave a tangible trace. Certainly the use of stone foundations, as evidenced in the larger house, appears not to have been a universal method of construction on the site, and may indicate that this structure was at least of some special significance. One of the smaller scoops at Chalbury was also excavated and turned out to be a pit, $1.2 \mathrm{~m}$ deep, which silted up naturally. This was probably too shallow to be considered as a storage pit, although the depths of such pits do vary considerably.

The relatively uncomplicated sequence of archaeological deposits at Chalbury provides us with a limited but relatively uncluttered picture of a hillfort constructed and occupied during the early years of the Iron Age. We can detect the construction of a well-designed defensible settlement which contained a number of houses carefully constructed and planned. How many of these were occupied at any one time is impossible to determine without further excavation, but of the 30-40 platforms to survive as surface depressions, it is certainly possible that a significant number may have been contemporary. The hillfort does not appear to have ended abruptly, and there is as yet little evidence to suggest that occupation continued beyond the Middle Iron Age. Certainly the pit excavated by Whitley silted up gradually and contained within its fills a few small sherds of pottery which possibly date to the Late Iron Age, but the overwhelming evidence from the pottery found on site suggests a predominantly Early Iron Age occupation.

Excavations at Poundbury in 1939, conducted by Katherine Richardson, examined the defences in the north west corner of this hillfort and determined that the largely bivallate enclosure had been constructed in at least two distinct phases. The Earlier Iron Age hillfort seems to have comprised a single rampart and ditch, subsequently remodelled in the Later Iron Age. The inner rampart was constructed from spoil obtained from its paired outer ditch, coupled with material excavated from a shallow inner quarry similar to that noted at Chalbury. The constructional form of the rampart consisted of an outer revetment built of vertically set posts, which probably braced horizontally laid timbers, and would have presented a vertical wall facing outwards. Behind this, chalk and earth was piled up to form the completed rampart. During 1939, a grid of 38 test pits was excavated in the interior of the hillfort, but they revealed little structural or artefactual evidence that would indicate intense settlement.

A more convincing case of Early Iron Age activity can be made for Bindon Hill whose earthworks comprise an earth rampart that is over $2.5 \mathrm{~km}$ in circuit which, along with the natural barrier of sea cliffs, encloses a massive 160 ha. Although there has been no excavation of the interior, the 'defences' were examined in 1950 when Mortimer Wheeler excavated two trenches through the long north rampart as well as making some investigations around the only known entrance (Wheeler 1953). The construction would seem to have been similar to that engineered by the builders of the first hillfort at Maiden Castle, namely a box rampart, the external face of which was probably intended to be faced by a palisade of vertical timbers, set within a continuous slot. The date of the earthworks has almost exclusively been based upon the ceramic forms discovered during the excavations, which comprised situlate pots with finger impressed decoration on the rim and shoulder. Whilst such wares are similar to those found at Maiden Castle, the absence of a haematite coating may indicate that the material is slightly earlier in date, although this is by no means certain. It is possible that the hill-top enclosure was constructed sometime between $800-600 \mathrm{BC}$.

Of the remaining hillforts excavated in Dorset, all have evidence of occupation within the Middle to Late Iron Age. At Hod Hill, the origin of the hillfort is conceivably attributable to the Early Iron Age, 
particularly as the first phase of the rampart is of box type construction, but the case is far from proven. The site was partially excavated by lan Richmond between $1951-8$ and posthumously published in 1968. An extensive survey of the hillfort's features undertaken by the Royal Commission on the Historical Monuments of England had revealed a dense concentration of roundhouses, yards and fences within the unploughed part of the interior, all of which were sampled by Richmond during his excavation campaign. Whilst Richmond's report includes a detailed account of his findings, the precise dating of the remains relied heavily on ceramics from the site. As with the material recovered from elsewhere, including Maiden Castle, the pottery remains largely unchanged throughout the Middle Iron Age, which males precise dating problematic. The evidence provided by the excavation would suggest that the occupation of the hillfort was to some extent continuous, possibly from as early as $400 \mathrm{BC}$. However the planned remains encountered are unlikely to be indicative of a single phase; they may even be intercutting or overlapping features, a palimpsest of unrelated chronological layouts of the settlement. Certainly many of the structures excavated by Richmond contained pottery of Durotrigian forms, which date to after $100 \mathrm{BC}$ and include small caches of slingstones. Some of the huts were also contained within their own palisades, which perhaps suggests, that they were occupied at a time of social stress. Richmond found that the ramparts had been remodelled at least twice, the early box rampart being partially buried within a later, higher dump rampart and ultimately faced with a stone revetment.

Eggardon was once again the subject of a series of small intrusive excavations, when between 1963 and 1966 George Rybot investigated a number of the internal earthworks contained within the southern half of the hillfort in the parish of Askerwell. The results of these excavations were summarily published by Caroline Wells (1978, 54-72). Rybot had examined a Bronze Age round barrow found within the hillforts interior along with eight pits and a number of upstanding earthwork of various forms. Pottery of middle to late Iron Age date was found in the pit fills (of which there are at least 123) confirming their likely contemporaneity with the occupation of the hillfort alongside the suggested presence of Iron Age hut circles and a pre-existing linear banks, although the dating of the latter is far from clear.

The excavation at Pilsdon Pen between 1964-71 by Peter Gelling (Gelling 1974), concentrated mainly on features within the interior of the hillfort. Several roundhouses were excavated which were largely defined by the presence of a U-shaped penannular gulley. Some of the houses contained postholes located either within the gullies themselves or inside the area defined by the gullies, which may indicate a variety of constructional techniques and perhaps that the houses were not necessarily contemporary. Dating the occupation was again essentially determined through associated pottery, which included surprisingly small quantities of abraded and largely undecorated jars and bowls which the excavator suggested were of earlier date than the more heavily decorated types associated with Durotrigian settlements of the $1^{\text {st }}$ century BC. Interestingly, the excavations at Pilsdon Pen indicated no evidence for four post structures or indeed of the ubiquitous deep pits which are to be found elsewhere. It is noteworthy that the landscape in this part of Dorset may have been dominated by a pastorally based economy and that consequently the storage of grain was not a significant element of the site's raison d'etre. As with Maiden Castle and Poundbury, there was evidence at Pilsden Pen to suggest metalworking, with the finding of crucible fragments, but this was quite limited.

As techniques and equipment improves, later excavations within the hillforts of Dorset have reexamined the earlier findings. Further excavations at Poundbury undertaken between 1966 and 82 (Green 1987) re-examined and re-evaluated the phases of the hillfort defences and, whilst broadly agreeing with the earlier conclusions, were able to establish a more complex constructional sequence. Excavation to the east of the defences also discovered the presence of an enclosure, only partially defined, which would seem to date from the Early Iron Age, although it may have been preceded by a Late Bronze Age enclosure constructed on a different alignment. Roger Mercer's study of the Neolithic activity on Hambledon Hill also included the examination of a cross-ditch within the area of the hillfort (Mercer \& Healey 2008) confirming the early origin of activity on the eastern spur. Additional work at Pilsdon Pen in 1982 disputed the dating of some linear features to the Late Iron Age, suggesting 
instead that they were pillow mounds built in the medieval period for the farming of rabbits (Thackray 1983).

One of the largest archaeological re-examinations of Iron Age hillforts in the area of the Durotriges was also the first to employ geophysical survey in order to identify and target specific features. In 1985-6 Niall Sharples conducted further excavation at Maiden Castle, casting doubt on some of Mortimer Wheeler's interpretation. It appears that whilst a box rampart may have existed around the eastern entranceway, the remainder of the rampart was probably a much less elaborate affair with earth and chalk piled behind a turf revetment. A road leading from the eastern entrance, furthermore, had a number of postholes adjacent to it, which could be interpreted as either a long house or alternatively a group of four-post structures, possibly granaries (Sharples 1991,61). It is in the interior of Maiden Castle hillfort that we see a clearer picture of activity and occupation during the Middle Iron Age. The excavations during the 1930s and the 1980s confirmed, for the most part the presence of roundhouses, four post structures and pits, all of which could be assigned to this period. It would seem that, following the rebuilding of the defences, the hillfort was only sparsely occupied, emphasis being placed upon a number of four post structures built directly behind the inner rampart. Whilst this can only be confirmed in the south east of the hillfort where excavation has taken place, similar findings on other hillforts in southern England, notably Danebury (Cunliffe 2003), suggest that the construction of this form of building is repeatedly found in the lee of the inner rampart. If these were granaries, it would seem they were relatively short lived, apparently being dismantled before the inner rampart was heightened.

The heightening of the inner rampart at Maiden Castle would seem to have been the last phase of defence strengthening during the Middle Iron Age. In rationalising this sequence, Sharples has suggested that the construction of granaries may have been to meet the needs of workers involved in the extensive rebuilding programme. However, whilst this hypothesis is entirely feasible, there is little real evidence to support it. Whatever the rationale of this early activity within the hillfort, there is evidence for later occupation, with the presence of a dense cluster of features, including roundhouses, fences and external hearths with, of course, the associated domestic refuse. This initial phase, however, appears not to demonstrate any signs of internal planning, which may suggest that occupation was at this time limited to discrete clusters, perhaps representing extended family units. The activity clusters were replaced after a period of abandonment by a much more regularly planned development of roundhouses in a line at the rear of the ramparts. These were constructed approximately $15 \mathrm{~m}$ behind the rampart and each appeared to have, within its allotted space, having access to a section of it. These allotments seem to have been work areas with traceable remains of metalworking being found in the form of bronze scrap (Sharples 1991, 97). A further indication of the level of organisation and planning associated with this phase of occupation was demonstrated by the presence of streets which, as a by-product, divide the settlement into 'zones', which subsequently may have been exploited to form distinct social units. This phase of settlement was replaced by about 100 $\mathrm{BC}$ by a return to occupation which is notably lacking in organisation, and is further marked only by limited evidence for any hut or house building.

Nearly all the phases of the Middle Iron Age occupation of Maiden Castle contain evidence for the presence of pits. The total number of pits is of course unknown, as only a small percentage of the total interior has been excavated. However, the number of pits found in the excavation campaigns has been estimated at about 290. The extrapolation of this figure over the whole of the hillfort would suggest that the total number of pits could have reached several thousand, which would indicate that they formed a significant function. The common interpretation is that they were utilised for the storage of grain. The presence of such features within hillforts may demonstrate that these enclosures functioned as 'grain banks' in which the accumulated wealth of the community was secured over the short term. 
Added references:

Colley March, H and Solly, H.S. 1901. A critical and material examination of the Hill-Fortress called Eggardun. Proceedings of the Dorset Natural History and Antiquarian Field Club. XXII, 28-42.

Wells, C. 1978. Excavations by the late George Rybot, FSA, On Eggardon Hillfort 1963-66. Proceedings of the Dorset Natural History and Archaeological Society. 100, 54-72. 